ningen og kostnadene knyttet til behandling av denne pasientgruppen.

\section{Konklusjon}

Statens strålevern er bekymret for den økende bruken av CT-undersøkelse i Norge. De skandinaviske retningslinjene for håndtering av minimale, lette og moderate hodeskader kan ha bidratt til at antall CT-undersøkelser av hodet ikke har økt etter 2002. Antallet kan sannsynligvis reduseres gjennom mer stringent etterfølgelse av retningslinjene. Scandinavian Neurotrauma Committee vurderer om det i tillegg bør innføres måling av S100B i serum som rutine før eventuell CT-undersøkelse hos denne pasientgruppen. Dette antas å kunne redusere både $\mathrm{CT}$-bruken og kostnadene ytterligere.

\section{Tor Ingebrigtsen \\ tor.ingebrigtsen@unn.no \\ Bertil Romner}

Tor Ingebrigtsen (f. 1963) er dr.med. og spesialist i nevrokirurgi. Han er administrerende direktør ved Universitetssykehuset Nord-Norge og professor II ved Det helsevitenskapelige fakultet, Universitetet i Troms $\varnothing$. Han er også styremedlem ved Oslo universitetssykehus. Forfatter har fylt ut ICMJE-skjemaet og oppgir følgende interessekonflikter: Han har fått reisetilskudd og tilskudd til S100B-analyser fra Sangtec, Diasorin og Roche Diagnostics.
Bertil Romner (f. 1953) er dr.med. og spesialist i nevrokirurgi. Han er overlege och professor ved Neurokirurgisk klinik, Rigshospitalet, København.

Forfatter har fylt ut ICMJE-skjemaet og oppgir følgende interessekonflikter: Han har fått reisetilskudd og tilskudd til S100B-analyser fra Sangtec, Diasorin og Roche Diagnostics.

\section{Litteratur}

1. Ingebrigtsen T, Rise IR, Wester K et al. Skandinaviske retningslinjer for håndtering av minimale. lette og moderate hodeskader. Tidsskr Nor Lægeforen 2000; 120: 1985-90.

2. Statement concerning the increased use of computed tomography in the Nordic countries. Statens strålevern 2012. www.nrpa.no/dav/db58f19fef.pdf (18.3.2012).

3. Hall P, Fransson A, Martens A et al. Datortomografi hos barn beräknas oka antalet cancerfall. Stråldos - och cancerrisk - kan reduceras. Läkartidningen 2005: 102: 214-5, 217, 220.

4. Børretzen I, Lysdahl KB, Olerud HM. Diagnostic radiology in Norway trends in examination frequency and collective effective dose. Radiat Prot Dosimetry 2007; 124: 339-47.

5. Radiologiske undersøkelser i Norge per 2008 Trender i unders $\varnothing$ kelsesfrekvens og stråledoser til befolkningen. Strålevernrapport 2010: 12. Østerås: Statens strålevern, 2010

6. Müller K, Waterloo K, Romner B et al. Mild head injuries: impact of a national strategy for implementation of management guidelines. J Trauma 2003; 55: 1029-34.

7. Heskestad B, Baardsen R, Helseth E et al. Guideline compliance in management of minimal, mild, and moderate head injury: high frequency of noncompliance among individual physicians despite strong guideline support from clinical leaders. J Trauma 2008; 65: 1309-13.
8. Heskestad B, Waterloo K, Ingebrigtsen T et al. An observational study of compliance with the Scandinavian guidelines for management of minimal, mild and moderate head injury. Scand J Trauma Resusc Emerg Med 2012: 20: 32 .

9. Flanagan ME, Ramanujam R, Doebbeling BN The effect of provider-and workflow-focused strategies for guideline implementation on provider acceptance. Implement Sci 2009; 4: 71.

10. Mazzocato P. Savage C. Brommels M et al. Lean thinking in healthcare: a realist review of the literature. Qual Saf Health Care 2010; 19: 376-82.

11. Müller K, Townend W, Biasca N et al. S100B serum level predicts computed tomography findings after minor head injury. J Trauma 2007; 62: $1452-6$.

12. Undén J, Bellner J, Astrand R et al. Serum S100B levels in patients with epidural haematomas. Br J Neurosurg 2005; 19: 43-5.

13. Zongo D, Ribéreau-Gayon R, Masson F et al. S100$B$ protein as a screening tool for the early assess ment of minor head injury. Ann Emerg Med 2012; 59: $209-18$.

14. Bouvier D, Fournier M, Dauphin JB et al. Serum $\mathrm{S} 100 \mathrm{~B}$ determination in the management of pedia tric mild traumatic brain injury. Clin Chem 2012; 58: $1116-22$

Mottatt 1.4. 2012, første revisjon innsendt 20.7. 2012, godkjent 16.8. 2012. Medisinsk redaktør Are Brean.

\title{
God stemning på landsstyremøtet
}

\author{
Det virker som om årets landsstyremøte gikk bra. Men jeg har noen spørsmål til presidenten.
}

«God stemning på landsstyremøtet.» «Helse må inn i all politikk.» «Fastlegeordningen skapte stort engasjement.» «Fastlegene til topps i ny undersøkelse.» «Fastlegeordningen fungerer godt.» «Tilfreds med legebehandling.» «Leger i Norge gjør en god jobb.» «Nordmenn er svært tilfredse med fastlegen sin. Det viser årets undersøkelse fra Norsk Kundebarometer. Fastlegene går helt til topps i kåringen over hvilke offentlige tjenester brukerne liker mest og minst $\mathrm{i}$ året som ligger bak oss.»

Så langt Aktuelt i foreningen i Tidsskriftets sommernummer. Dette virker betryggende og er hyggelig lesing - nærmest optimalt.

Det jeg ikke kan se komme frem fra referatene fra landsstyremøtet, er hvilke spørsmål som er blitt stilt av Norsk Kundebarometer. Hva slags spørsmål? Hvordan er spørsmålene stilt? Har pasientene skjønt hva de har svart på?
Legeforeningens president Hege Gjessing har etter min mening skjønt mye når hun hevder at helsetjenesten må tuftes på kvalitet og at ny kunnskap må tas i bruk så raskt som mulig. Mener hun at ny kunnskap skal implementeres raskt i fastlegens armamentarium? Hva slags kunnskap tenker hun på?

«Tror vi virkelig at vi kan medisinere oss vekk fra effekten av manglende forebygging?» spurte en annen debattant. Jeg mener at med dagens organisering av fastlegeordningen har legene ikke tid til å drive optimal forebygging. Legene har forutsetningene, men mangler tid. For med dagens avlønningssystem er nok sjansene for slik virksomhet begrenset langt frem i tid. Dette med legens tid er også bestemmende for hvor realistisk det er få realisert forslag til samhandlingsreformen. Slike innspill kan jo bare komme fra departementet. Det er så rart, det der, det slår nesten aldri feil. De som har satt seg ned for å tegne kartet, har det til felles at de har så godt som aldri vært $i$ terrenget. Og om de har vært innom der, har de skjønt lite.

Stå på, kjære president. Jeg synes du har mange fine innspill og uttalelser, men jeg er redd du kommer til å måtte kjempe mot mange inkompetente vindmøller på ferden.

Einar Skatteboe
einskat@online.no

Einar Skatteboe (f. 1936) er pensjonert spesialist i samfunnsmedisin.

Ingen oppgitte interessekonflikter.

Mottatt 20.8. 2012 og godkjent 26.8. 2012. Medisinsk redaktør Erlend Hem. 